\title{
Correction to: The essence of autism: fact or artefact?
}

\section{Robert Chapman (1) - Walter Veit (1)}

Published online: 26 October 2021

(c) The Author(s), under exclusive licence to Springer Nature Limited 2021

\section{Correction to: Molecular Psychiatry}

https://doi.org/10.1038/s41380-020-00959-1

There was a typographic error in the title of this article.

'The Essence of Autism: Face or Artefact?' should have read 'The Essence of Autism: Fact or Artefact?'. This has now been corrected in both the PDF and HTML versions of this article. 